\title{
A new Myxobolus (Cnidaria: Myxosporea) infecting the ornamental catfish Corydoras schwartzi from the Purus River in Brazil
}

\author{
Patrick D. MATHEWS ${ }^{1, *}$, Rafael R.M. MADRID ${ }^{2}$, Omar MERTINS $^{3}$, \\ Vera L.S. RIGONI ${ }^{4} \&$ André C. MORANDINI ${ }^{5}$ \\ ${ }^{1,2,3,4}$ Department of Biophysics, Paulista Medical School, Federal University of São Paulo, \\ 04023-062 São Paulo, Brazil. \\ ${ }^{1,5}$ Department of Zoology, Institute of Biosciences, University of São Paulo, \\ 05508-090 São Paulo, Brazil. \\ ${ }^{5}$ Marine Biology Center (CEBIMar), University of São Paulo, 11600-000 São Sebastião, Brazil. \\ *Corresponding author: patrickmathews83@gmail.com \\ ${ }^{2}$ Email: rmadrid@unicolmayor.edu.co \\ ${ }^{3}$ Email: mertinso@gmail.com \\ ${ }^{4}$ Email: vera.jacomino@gmail.com \\ ${ }^{5}$ Email: acmorand@ib.usp.br

\footnotetext{
${ }^{1}$ urn:Isid:zoobank.org:author:4C8F5661-BF0C-4DC8-9717-F7ACB2610960

${ }^{2}$ urn:1sid:zoobank.org:author:4932ACBF-4249-463A-9A26-3C00C756FE59

${ }^{3}$ urn:1sid:zoobank.org:author:4B10B638-55B2-4682-B159-1EC148846774

${ }^{4}$ urn:lsid:zoobank.org:author:80CE4042-FFAF-4CB9-839E-4751CB12883B

${ }^{5}$ urn:1sid:zoobank.org:author:BAC1897A-5367-40BB-8CD3-A9F293A21423
}

\begin{abstract}
A new microscopic cnidarian is described, infecting five of thirty (16.6\%) specimens of Corydoras schwartzi caught in the Purus River, State of Amazonas, Brazil. Histological analysis showed that cyst development occurred in the serosa layer of the intestine. Mature myxospores are ovoid in body shape in frontal view, $22.4 \pm 0.3 \mu \mathrm{m}$ in total length and $16.3 \pm 0.1 \mu \mathrm{m}$ in width. Internally, two aubergine-shaped, elongate symmetrical polar capsules occupy more than half the length of the spore, $14.3 \pm 0.2 \mu \mathrm{m}$ in length and $6.5 \pm 0.1 \mu \mathrm{m}$ in width. Ultrastructural analysis provided evidence of five polar filament coils inside the polar capsule and binucleated sporoplasm containing a moderate number of sporoplasmosomes. The valvogenic cells abutting each other form a sutural ridge and frequently a thin layer of homogeneous material separates the cells. The outer surface of the myxospore valves is smooth, with no evidence of formation of ridges in the valves. Immature myxospores in various stages of development were observed. This study is the first report of a myxosporean parasitizing C. schwartzi and the first report of a myxosporean infection in the intestine of an ornamental fish from South America.
\end{abstract}

Keywords. Amazon, intestinal infection, myxosporean, ultrastructure.

Mathews P.D., Madrid R.R.M, Mertins O., Rigoni V.L.S. \& Morandini A.C. 2020. A new Myxobolus (Cnidaria: Myxosporea) infecting the ornamental catfish Corydoras schwartzi from the Purus River in Brazil. European Journal of Taxonomy 620: 1-14. https://doi.org/10.5852/ejt.2020.620 


\section{Introduction}

Within Phylum Cnidaria, myxozoans are microscopic endoparasites of worldwide distribution and with approximately 2400 species they represent around $20 \%$ of cnidarian species diversity (Zhan et al. 2013; Atkinson et al. 2018). Myxozoans have a complex life cycle that typically involves invertebrates and vertebrates as definitive and intermediate hosts, respectively (Okamura et al. 2015).

In the last years, a large number of myxosporean species has been described infecting different organs and tissues of wild and farmed South American freshwater fish (Mathews et al. 2015; Velasco et al. 2016; Vidal et al. 2017; Abrunhosa et al. 2017; Capodifoglio et al. 2019), with some species causing considerable pathological issues such as reduction of epithelial area of the gill, myocarditis of the heart, deformation, displacement, retraction and compression of capillaries of the gill lamellae, large skin nodules, thickening of the tunica externa of the swim bladder with granulomatous reaction, perivascular edema in the interlamellar area, and stretching of the corneal epithelium and urinary bladder (Barassa et al. 2003; Adriano et al. 2009; Naldoni et al. 2009; Matos et al. 2014).

Although there are several myxosporean infection surveys of South American teleosts, information on ornamental freshwater fish is still scarce, particularly from the Amazon region (Mathews et al. 2018) given the richness in species living in the greatest interconnected freshwater fluvial system in the world (Junk et al. 2007; Moreau \& Coomes 2007). Within the Amazonian ornamental teleosts, smaller catfishes, particularly species belonging to the genus Corydoras Lacépède, 1803, have great diversity with approximately 162 described species and are of considerable economic importance due to wide commercialization in the international aquarium pet industry (Reis 1998; Prang 2007). Corydoras schwartzi Rössel, 1963 is a member of Siluriformes belonging to the family Callichthyidae Bonaparte, 1838, endemic of the Purus River basin in Brazil. It can reach up to $5 \mathrm{~cm}$ in total length and inhabits blackwater-flooded forests and the littoral zone of slow flow rivers (Froese \& Pauly 2018).

To our knowledge, nothing is known about myxosporeans infecting specimens of C. schwartzi. The present study describes a new species of Myxobolus Bütschli, 1882 infecting the intestine of C. schwartzi from Lábrea Municipality in the Amazon region of Brazil, a key supply region of this species to international aquarium markets.

\section{Material and methods}

Between October and November 2018, thirty specimens of C. schwartzi (ranging from 3.9 to $4.2 \mathrm{~cm}$ in total length and 2.3 to $2.7 \mathrm{~g}$ in weight) (Fig. 1A) were caught in the Purus River, near the Municipality of Lábrea ( $7^{\circ} 15^{\prime} 32^{\prime \prime}$ S, 64 $47^{\prime} 52^{\prime \prime}$ W), State of Amazonas, Brazil. The fish sample access was authorized by the Brazilian Ministry of the Environment (SisGen Process No. A5BD085). Fish were transported alive to the field laboratory and euthanized by a benzocaine overdose $\left(400 \mathrm{mg}^{-1}\right)$, in accordance with Brazilian law for scientific use of animals (Federal Law No. 11794, dated 8 October 2008) and all organs were examined for myxosporean infection using a light microscope. Mature myxospores fixed in $10 \%$ formalin were transported to the Department of Biophysics, Federal University of São Paulo, and morphological and morphometric analyses were performed based on the criteria outlined by Lom \& Arthur (1989). Measurements and photographs were taken of 30 myxospores using a Leica DM1000 LED compound microscope equipped with Leica Application Suite version 1.6.0 image capture software. Smears containing free myxospores were air-dried, fixed with methanol and stained with Giemsa solution to mount on permanent slides that were deposited in the collections of the Museum of Zoology of the University of São Paulo - USP, São Paulo, Brazil (MZUSP).

For transmission electron microscopy, samples were fixed in $2.5 \%$ glutaraldehyde diluted in $0.1 \mathrm{M}$ sodium cacodylate buffer ( $\mathrm{pH}$ 7.4) for $12 \mathrm{~h}$, washed in a glucose-saline solution for $2 \mathrm{~h}$, and post-fixed 

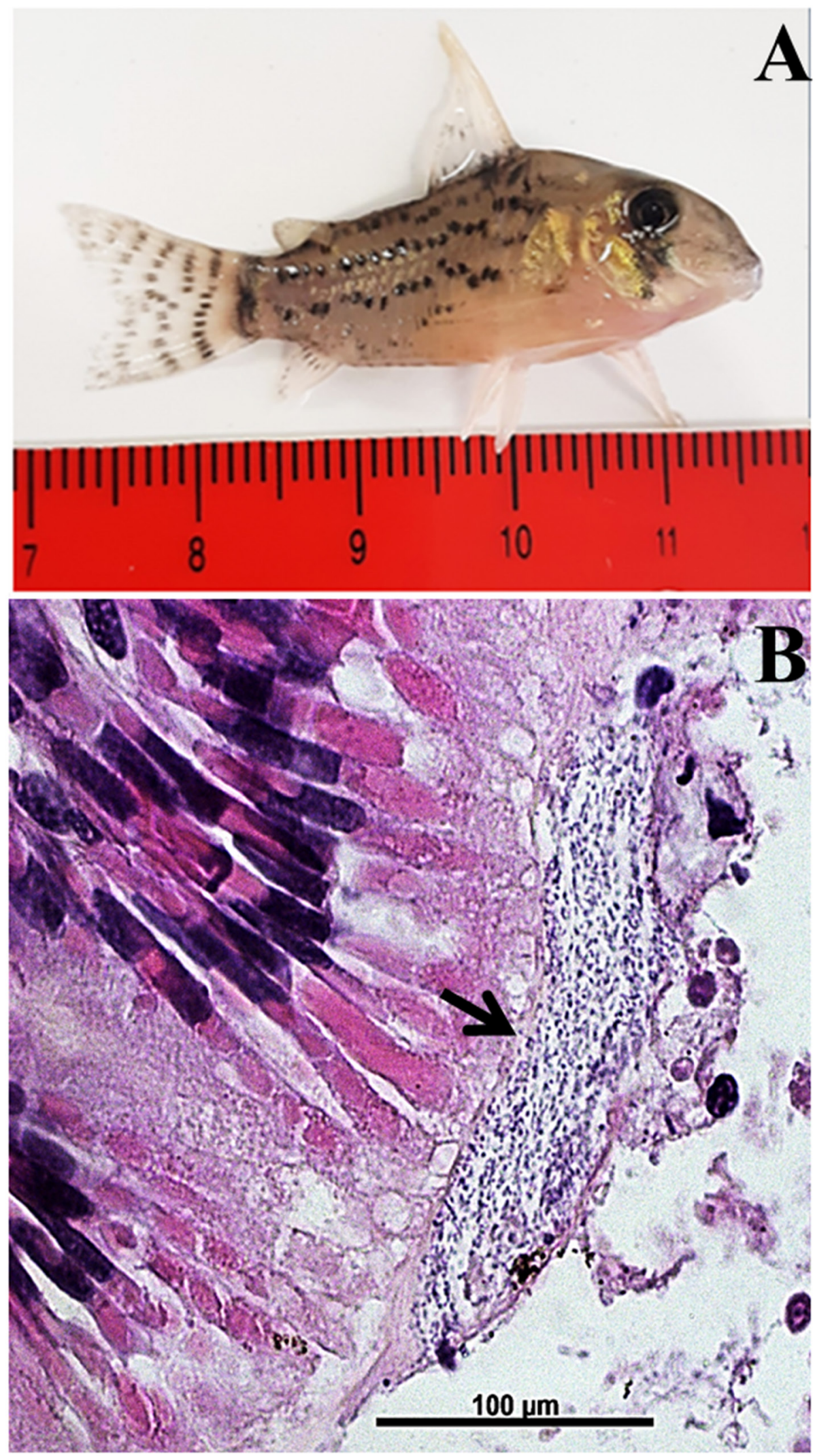

Fig. 1. Corydoras schwartzi Rössel, 1963 infected by Myxobolus adrianoi sp. nov. A. Sampled fish captured in the Purus River near Lábrea Municipality, Amazonas State, Brazil. B. Histological sections of the fish intestine showing large cyst in the serosa layer (black arrow). 
in $2 \%$ osmium tetroxide $\left(\mathrm{OsO}_{4}\right)$ for 4 to $5 \mathrm{~h}$. After dehydration in an ascending concentration of ethanol series, the samples were embedded in EMbed 812 resin (Electron Microscopy Sciences, Hatfield, PA, USA). Ultrathin sections, double stained with uranyl acetate and lead citrate, were examined in a LEO 906 electron microscope operating at $60 \mathrm{kV}$.

For the histological analysis, fresh fragments of infected tissues containing cysts were fixed in a $10 \%$ buffered formalin solution, dehydrated in an increasing concentration series of ethanol, diaphanized, embedded in paraffin, cut into serial sections $5 \mu \mathrm{m}$ thick using a Leica RM2255 automated microtome and stained with hematoxylin-eosin. Images were captured using a Leica DM 1000 microscope coupled to a computer and using Leica Application Suite software ver. 1.6.0 for image capture.

\title{
Results
}

In the present study, cysts of an unknown species of Myxobolus were found in the intestine of five specimens of C. schwartzi. Cysts were ellipsoidal elongated in shape, measuring up to $213.6 \mu \mathrm{m}$ in length and $38.8 \mu \mathrm{m}$ in width (Fig. 1B). Histological analysis of infected tissues revealed that cyst development occurred in the serosa layer of the intestine of C. schwartzi (Fig. 1B). They were not found in any other organs and no clinical symptoms were observed in the parasitized intestines.

\author{
Phylum Cnidaria Verrill, 1865 \\ Class Myxosporea Bütschli, 1881 \\ Order Bivalvulida Shulman, 1959 \\ Family Myxobolidae Thélohan, 1892 \\ Genus Myxobolus Bütschli, 1882 \\ Myxobolus adrianoi sp. nov. \\ urn:1sid:zoobank.org:act:9FF87134-46B5-47AD-98FE-B97E6F913645
}

Figs $1-4$

\section{Etymology}

The specific name, adrianoi, is in homage to Dr. Edson Adriano, Professor at Federal University of São Paulo, Brazil, who has been contributing to improving our knowledge on the diversity of South American Myxosporea.

\section{Material examined}

Syntypes

BRAZIL • 10+ myxospores; Amazonas State, Lábrea Municipality; $7^{\circ} 15^{\prime} 32^{\prime \prime} \mathrm{S}, 64^{\circ} 47^{\prime} 52^{\prime \prime} \mathrm{W}$; air-dried slide stained with Giemsa; MZUSP 8469.

\section{Type host}

Corydoras schwartzi Rössel, 1963 (Siluriformes: Callichthyidae).

\section{Site of infection}

Serosa layer of intestine.

\section{Prevalence}

From 30 examined fish, five were infected (16.6\%). 


\section{Description}

Mature myxospores ovoid in body shape in frontal view, showing two aubergine-shaped, elongate symmetrical polar capsules occupying more than half length of spore. Total myxospore length $22.4 \pm 0.3 \mu \mathrm{m}$ and width $16.3 \pm 0.1 \mu \mathrm{m}$. Two polar capsules, $14.3 \pm 0.2 \mu \mathrm{m}$ in length and $6.5 \pm 0.1 \mu \mathrm{m}$ in width (Figs 2A-D, 3).

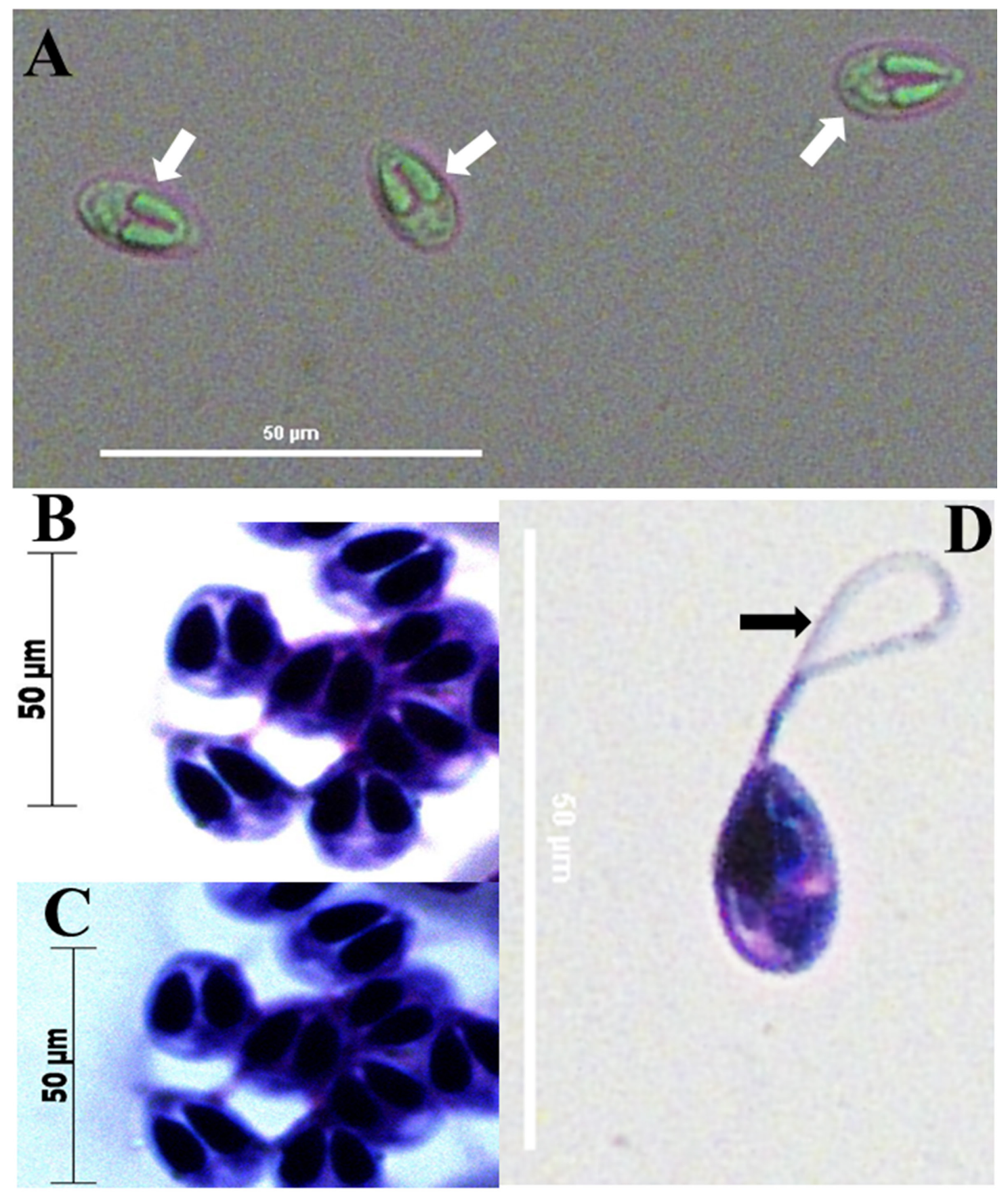

Fig. 2. Light photomicrograph of mature myxospores of Myxobolus adrianoi sp. nov., parasite of the intestine of Corydoras schwartzi Rössel, 1963. A. Wet-mount mature myxospores (white arrows). B-C. Frontal view of mature myxospores stained in May-Grünwald-Giemsa, showing two equal polar aubergine-like capsules, occupying more than half the length of the myxospore. D. Mature myxospore stained, in frontal view, with the polar filament extruded (black arrow). 
Ultrastructural analysis showed myxospores in various stages of development. In young developmental myxospore stage, the polar filament could still be observed out of the polar capsules and valvogenic cells were readily recognized by valve-forming materials (Fig. 4A). In myxospores at a more advanced developmental stage, a polar filament inside the polar capsule and binucleated sporoplasms containing a moderate number of sporoplasmosomes were observed (Fig. 4B-C). Transverse sections of a polar capsule provided evidence of a polar filament with five coils (Fig. 4B-C). Sections of immature myxospores show the valvogenic cells abutting each other to form a sutural ridge, and frequently the two cells were separated by a thin layer of homogenous material (Fig. 4D). Almost mature myxospores showed sutural lines, valve-forming material, valves, two nuclei and sporoplasmosomes at sporoplasms (Fig. 4E-F). The outer surface of the myxospore valves was smooth, with no evidence of formation of ridges in the valves (Fig. 4E-F).

\section{Discussion}

Although Corydoras spp. display a broad diversity and are widely exploited as an important source in the international aquatic pet trade, there are few studies about myxosporean infections in these smaller catfishes (Mathews et al. 2017). Among approximately thirty-two species of Myxobolus described as infecting wild and farmed fish from the Amazon River basin and its main tributaries (Eiras et al. 2014; Abrunhosa et al. 2017; Naldoni et al. 2018; Capodifoglio et al. 2019), only one species was reported to infect Corydoras spp., i.e., Myxobolus niger Mathews, Maia \& Adriano, 2016 described from the gill arch of C. melini Lönnberg \& Rendahl, 1930 (Mathews et al. 2016). Our study reports, for the first time,

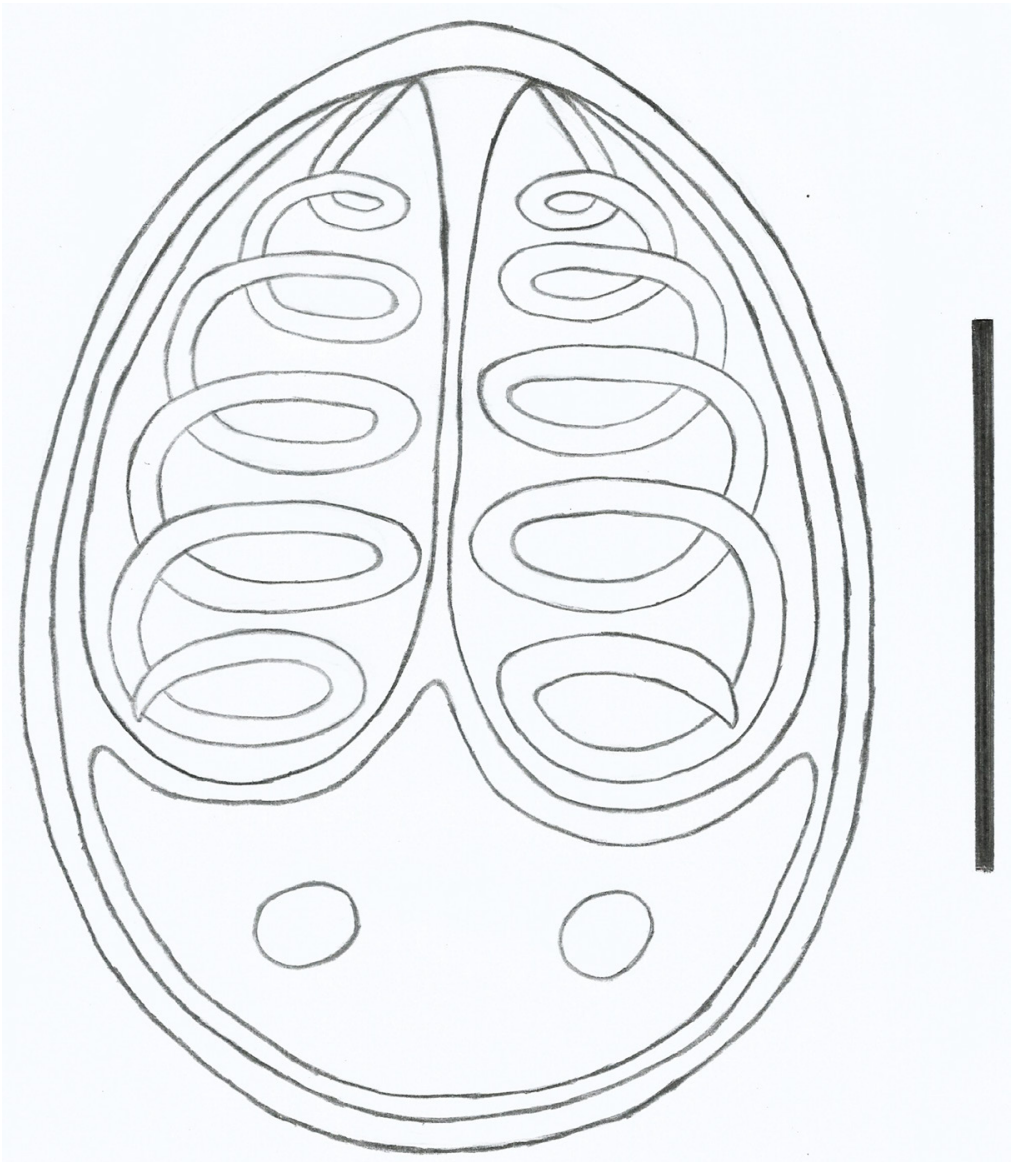

Fig. 3. Schematic representation of the mature myxospore Myxobolus adrianoi sp. nov., parasite of intestine of the Corydoras schwartzi Rössel, 1963. Scale bar: $10 \mu \mathrm{m}$. 
a myxosporean species infecting C. schwartzi from the Amazon region and is hence the second to report a Myxobolus infection in Corydoras fish from South America.

The morphometric data of the myxospore sample obtained were first compared with those of M. niger, the unique species of Myxobolus previously described infecting Corydoras fish. Indeed, the comparison showed a large number of noticeable morphological and morphometric differences, with mature myxospores ovoid in shape for the myxobolids obtained in our study and ellipsoidal elongate for $M$. niger. The newly identified myxospores are substantially larger in length and width $(22.4 \pm 0.3 \mu \mathrm{m}$ in length and width of $16.3 \pm 0.1 \mu \mathrm{m}$ in the present study and $11.3 \pm 0.4 \mu \mathrm{m}$ in length and $6.8 \pm 0.2 \mu \mathrm{m}$ in width in M. niger $)$. In the same way, the two polar capsules are longer and wider $(14.3 \pm 0.2 \times 6.5 \pm 0.1 \mu \mathrm{m}$ in the present study and $5.0 \pm 0.3 \times 2.0 \pm 0.1 \mu \mathrm{m}$ in $M$. niger $)$. Differences may also be observed in the number of coils in the polar filament (four coils in the present study and six to seven coils in M. niger). The new species was compared with the four species of Myxobolus previously described infecting the intestine of South American freshwater fish: M. cunhai Penido, 1927, a parasite of Pimelodus clarias maculatus Lacepède, 1803; M. pygocentrus Penido, 1927, which infects Pygocentrus piraya Cuvier, 1819; M. colossomatis Molnár \& Békési, 1993, which infects Colossoma macropomum Cuvier, 1816; and M. marajoensis Abrunhosa, Sindeaux-Neto, dos Santos, Hamoy \& Matos, 2017, described from Rhamdia quelen Quoy \& Gaimard, 1824 (Molnár 1993; Eiras et al. 2014; Abrunhosa et al. 2017). Noticeable morphometric differences were observed between these species and M. adrianoi sp. nov., as shown in Table 1.

Concerning the host-specificity, freshwater histozoic platysporines, particularly the species belonging to the genera Myxobolus and Henneguya Thélohan, 1892, have demonstrated high/strict specificity to parasitize a single host (Molnár \& Eszterbauer 2015). Thus, this feature has been used to aid in the classification of myxosporeans. As a matter of fact, several studies on South American freshwater fish have corroborated this finding. For instance, Zatti et al. (2018a), in a study conducted on the myxobolids of two Amazonian cichlids, Cichla monoculus Spix \& Agassiz, 1831 and Cichla pinima Kullander \& Ferreira, 2006 collected in different areas of the Brazilian part of the Amazon Basin, reported that in the lower Tapajós region, where both fish species are sympatric, the species Henneguya tapajoensis Zatti, Atkinson, Maia, Bartholomew \& Adriano, 2018 was found infecting only C. pinima. Likewise, Adriano et al. (2002), studying myxosporeans of four different characiforms confined in a cultured pond (Prochilodus lineatus Valenciennes, 1836, Piaractus mesopotamicus Holmberg, 1887, Brycon cephalus Günther, 1869 and Leporinus copelandii Steindachner, 1875), reported Myxobolous porofilus Adriano, Arana, Ceccarelli \& Cordeiro, 2002 infecting exclusively Prochilodus lineatus. Actually, our results are in agreement with these studies, given that although $M$. niger has previously been described in C. melini, a genetically close related species to C. schwartzi, this myxosporean species was not found in the present study, thus reinforcing the fine-scale of the host specificity of species of Myxobolus. According to Morand \& Guégan (2000), host-specificity may be more pronounced in populations inhabiting restricted spaces, due the fact that areas of host endemism are also areas of parasite endemism on a regional scale for freshwater fish. Indeed, the majority of Corydoras spp. usually inhabit restricted areas of endemism within the Amazon Basin (Reis 1998), as is the case with C. schwartzi and C. melini, both species with a restricted distribution. Actually, the distribution of C. schwartzi is restricted to the Purus River and C. melini to the Rio Negro River, both rivers separated by a distance of $703 \mathrm{~km}$ from each other, which is sufficient to allow speciation of their myxosporean species, considering that generally, geographic isolation plays an important role in population divergence (Wang et al. 2019).

On the same premise, organ and/or tissue specificity has been considered a taxonomic key for the identification of freshwater histozoic platysporines, particularly for species belonging to the genus Myxobolus (Molnár 2002; Molnár et al. 2014). Accordingly, differences are observed in the infected tissue in the intestine when comparing the four species of Myxobolus for which information is 
available in the literature to the new species described herein (intestinal wall in $M$. cunhai and M. pygocentrus, mucosa layer in M. colossomatis, muscle layer in M. marajoensis and serosa layer in the new species). Furthermore, these species of Myxobolus were found parasitizing fish belonging to the families Pimelodidae, Heptapteridae, and Characidae. Considering M. niger, which was described from Corydoras melini, the closest host species to C. schwartzi, the comparison showed that both species differ in the organ/tissue they were found to have infected, with the new species in the serosa layer of the intestine and M. niger in the gill arch. In the present study, a species of Myxobolus is thus described for the first time infecting the intestine of a fish belonging to Callichthyidae, which is endemic to South America. Moreover, this is the first report of intestinal infection by myxosporeans in an ornamental fish from the Amazon Basin.

According to Zatti et al. (2018a), host behavior may drive both parasite endemism and the radiation of myxosporeans within the Amazon Basin. These authors observed differences in the number of host species infected by a given species of myxosporean in a study conducted on species of the genus Cichla Schneider, 1801, which have differences in their distribution within the Amazon Basin. Similarly, Zatti et al. (2018b) described the presence of Ceratomyxa gracillima Zatti, Atkinson, Maia, Bartholomew \& Adriano, 2018 in populations of the Amazonian catfish Brachyplatystoma rousseauxii Castelnau, 1855 collected at localities of wide geographic separation and considered that this finding is a result of the exceptionally long-distance migration of this fish. In addition, Whipps \& Kent (2006) suggested that host distribution and migration are important factors in maintaining parasite gene flow over broad geographic areas. The above-mentioned studies reinforce the conclusion that host ecological characteristics may be important in aiding the characterization of the myxobolid fauna within the Amazon Basin, particularly for those species that infect Corydoras spp., considering the endemic character and the absence of migratory reproduction in this group of small catfishes. Thus, taking into account the ecological characteristics of the host examined in our study, which are its high endemism and nonmigratory behavior, the designation of the Myxobolus found herein as a new species is reinforced.

From a pathological point of view, several studies have reported that myxosporeans are implicated in causing histological damage and mortality in wild and cultivated ornamental fish (Crawshaw \& Sweeting 1986; Padrós et al. 2001; Camus \& Griffin 2010; Saha \& Bandyopadhyay 2017). Although Myxobolus adrianoi sp. nov. induced no apparent tissue destruction or inflammatory response in the specimens of Corydoras schwartzi in our study, previous studies of Amazonian ornamental fish have reported lymphocytic meningoencephalomyelitis associated with infection by Myxobolus sp. in the central nervous system of Eigenmannia sp. (Sindeaux-Neto et al. 2016). Furthermore, Camus et al. (2017) in

Fig. 4 (next page). Electron micrographs of myxospores of Myxobolus adrianoi sp. nov., parasite of the intestine of Corydoras schwartzi Rössel, 1963. A. Young sporoblast showing polar filament still out of the polar capsules, abundant valve-forming material, conspicuous sutural line (large white arrow), some sporoplasmosomes (small white arrows), mitochondria and presence of pinocytic channels (white arrowheads) in the ectoplasm. B-C. Sporoblast in advanced developmental stage with polar filament (white arrows) inside the polar capsule. In B note several sporoplasmosomes (white arrows) and two nuclei at sporoplasms. In C observe presence of valve-forming material (short white arrows), capsulogenic cell, nuclei at sporoplasm and nucleus of capsulogenic cell. D. Immature myxospore showing valvogenic cells abutting each other to form a sutural ridge and showing the two cells are separated by a thin layer of homogenous material (white arrow). E-F. Almost mature myxospores showing sutural lines (black arrows), valve-forming material (*), valves, two nuclei and sporoplasmosomes (white arrows) at sporoplasms. Abbreviations: $\mathrm{cp}=$ capsulogenic cell; $\mathrm{ec}=$ ectoplasm; $\mathrm{mt}=$ mitochondrion; $\mathrm{nc}=$ nucleus of capsulogenic cell; $\mathrm{Nu}=$ nucleus; $\mathrm{pc}=$ polar capsule; $\mathrm{PF}=$ polar filament; $\mathrm{sp}=$ sporoplasm; $\mathrm{v}=$ valvogenic cell/valve; vm = valve-forming material. Scale bars: $2 \mu \mathrm{m}$. 


\section{MATHEWS P.D. et al., A new species of Amazonian microscopic cnidarian from Brazil}

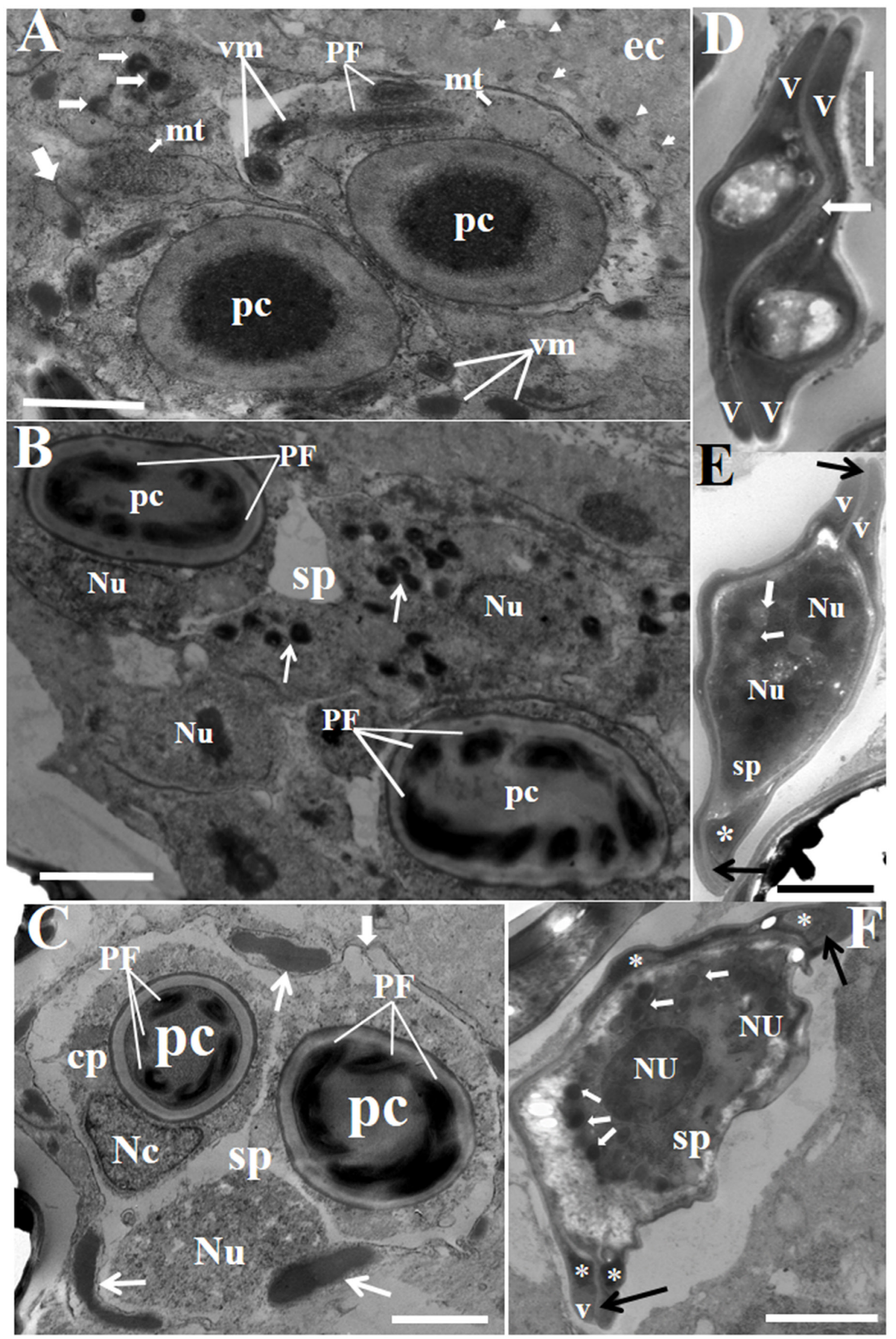




\begin{tabular}{|c|c|c|c|c|c|c|}
\hline 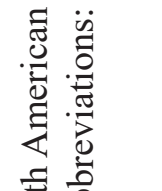 & 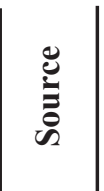 & 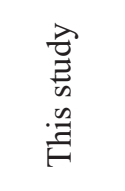 & 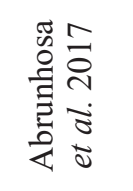 & $\begin{array}{l}\widehat{\widehat{N}} \\
\frac{0}{0} \\
\frac{0}{0} \\
0\end{array}$ & 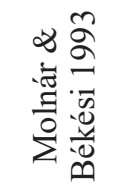 & 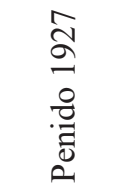 \\
\hline 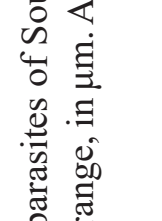 & 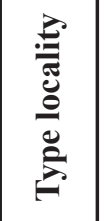 & 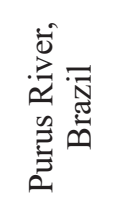 & 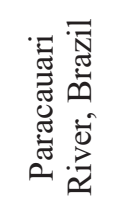 & $\begin{array}{l}\overline{\bar{N}} \\
\bar{n} \\
\bar{n}\end{array}$ & 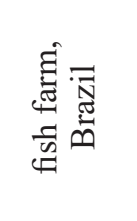 & 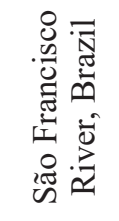 \\
\hline 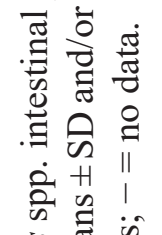 & 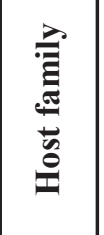 & 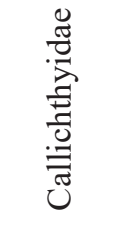 & 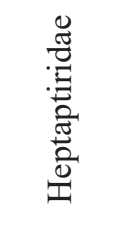 & 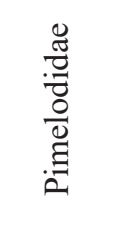 & $\begin{array}{l}\frac{\pi}{\pi} \\
\frac{\pi}{\pi} \\
\frac{\pi}{\pi} \\
\text { U }\end{array}$ & 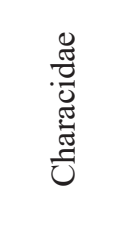 \\
\hline 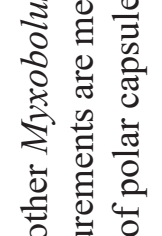 & 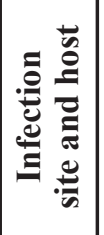 & 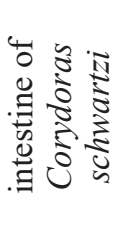 & 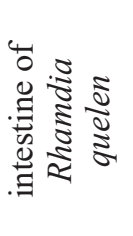 & 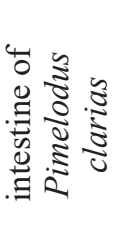 & 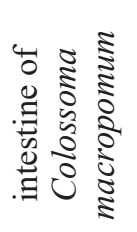 & 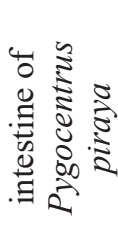 \\
\hline 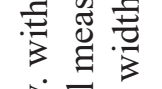 & $\frac{5}{Z}$ & in & 1 & 1 & $\wedge$ & 1 \\
\hline 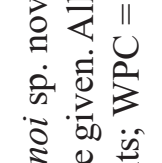 & $\sum_{2}^{u}$ & $\begin{array}{l}- \\
0 \\
+1 \\
n \\
0\end{array}$ & 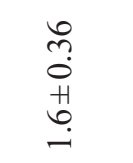 & 1 & $\begin{aligned} \stackrel{n}{n} \\
\vec{i} \\
\stackrel{\infty}{=}\end{aligned}$ & $\underset{m}{+}$ \\
\hline 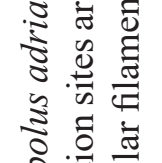 & $\underset{U}{U}$ & $\begin{array}{l}\stackrel{Y}{0} \\
+ \\
\dddot{H} \\
\dddot{ \pm}\end{array}$ & $\begin{array}{l}0 \\
0 \\
\text { H } \\
\text { in }\end{array}$ & 1 & $\begin{array}{l} \\
0 \\
0 \\
0 \\
0 \\
0 \\
0 \\
0 \\
0\end{array}$ & $\bar{a}$ \\
\hline 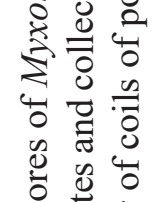 & 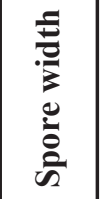 & 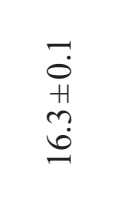 & 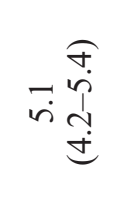 & f & a) & $\bar{a}$ \\
\hline 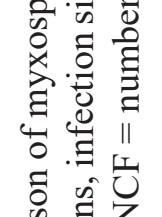 & 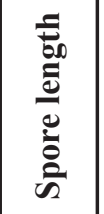 & 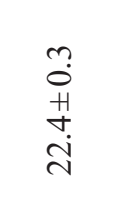 & $\begin{array}{l}\stackrel{0}{0} \\
\stackrel{\bar{\Xi}}{0} \\
\stackrel{0}{0}\end{array}$ & $\bar{a}$ & 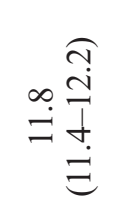 & $\begin{array}{l}0 \\
\stackrel{1}{n} \\
\end{array}$ \\
\hline 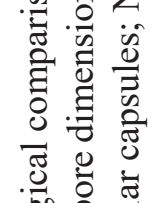 & 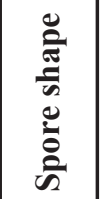 & $\begin{array}{l}\overline{0} \\
0 \\
0 \\
0\end{array}$ & 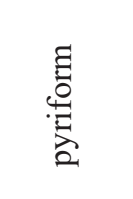 & 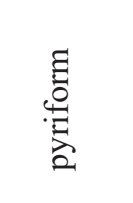 & 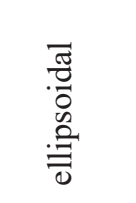 & 1 \\
\hline 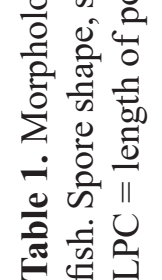 & 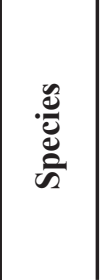 & 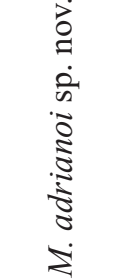 & 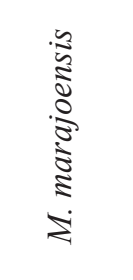 & 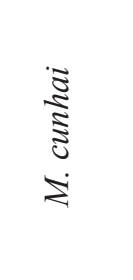 & 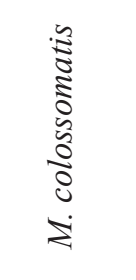 & 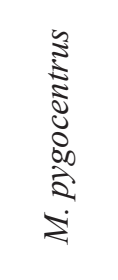 \\
\hline
\end{tabular}


MATHEWS P.D. et al., A new species of Amazonian microscopic cnidarian from Brazil

an investigation of mortality in a group of cardinal tetras suggested that infection by Myxobolus axelrodi Camus, Dill, Rosser, Pote \& Griffin, 2016 in ventricles of the brain and the ocular retina predisposed this group to opportunistic bacterial infection, including bacterial dermatitis and meningitis. There are, however, few published surveys of myxosporeans in Amazonian ornamental fish. Thus, further studies are necessary not only to increase our knowledge of the diversity of myxosporeans, but furthermore to evaluate their pathogenicity, taking into account that the Amazon Basin is the most important source of wild-caught freshwater fishes for the global aquarium trade and considering that increased global connectivity with shorter transportation times, favor hosts and their parasites arriving in a viable state to new environments (Hallett et al. 2015).

In our study, DNA extraction was performed, but no sufficient DNA was obtained for standardizing PCR reactions; hence, the amplification of SSU rDNA from the myxospores failed. In addition, there are limitations in accessing new samples from the same region. However, based on the morphological/ morphometric features observed under light and transmission electron microscopy, geographic isolation, host endemism and host-, tissue- and organ-specificity, the surveys corroborate the establishment of M. adrianoi sp. nov. as a new species o Myxobolus. Furthermore, the results contribute to studies of platysporine taxonomy and in extending our knowledge about myxosporean parasites of ornamental fish from the Amazon Basin, which is a key supplier of wild freshwater fishes to the multi-billion dollar global aquarium trade (Moreau \& Coomes 2007).

\section{Acknowledgments}

The authors thank the São Paulo Research Foundation, FAPESP, for a Post-Doc fellowship awarded to P.D. Mathews (grant no. 2018/20482-3). O. Mertins thanks FAPESP for research financial support (2015/23948-5; 2016/13368-4). A.C. Morandini was funded by CNPq (304961/2016-7) and FAPESP (2015/21007-9). The authors thank Gisela R.S. Sasso and Paulo C. Franco for assistance with histological processing and Prof. Dr Eric O. Thomas from the University of the Pacific for previous advise on Corydoras origin and identification.

\section{Disclosure statement}

The authors declare that they have no conflict of interest.

\section{References}

Abrunhosa J., Sindeaux-Neto J.L., Dos Santos Â.K., Hamoy I. \& Matos E. 2017. Myxobolus marajoensis sp. n. (Myxosporea: Myxobolidae), parasite of the freshwater catfish Rhamdia quelen from the Brazilian Amazon region. Revista Brasileira de Parasitologia Veterinária 26: 465-471. https://doi.org/10.1590/s1984-29612017067

Adriano E.A., Arana S., Ceccarelli P.S. \& Cordeiro N.S. 2002. Light and scanning electron microscopy of Myxobolus porofilus sp. n. (Myxosporea: Myxobolidae) infecting the visceral cavity of Prochilodus lineatus (Pisces: Characiformes: Prochilodontidae) cultivated in Brazil. Folia Parasitologica 49 (4): 259-262. https://doi.org/10.14411/fp.2002.049

Adriano E.A., Arana S., Alves A.L., Silva M.R.M., Ceccarelli P.S., Henrique-Silva F. \& Maia A.A.M. 2009. Myxobolus cordeiroi $\mathrm{n}$. sp., a parasite of Zungaro jahu (Siluriformes: Pimelodidae) from Brazilian Pantanal: Morphology, phylogeny and histopathology. Veterinary Parasitology 162: 221-229. https://doi.org/10.1016/j.vetpar.2009.03.030

Atkinson S.D., Bartholomew J.L. \& Lotan T. 2018. Myxozoans: Ancient metazoan parasites find a home in phylum Cnidaria. Zoology 129: 66-68. https://doi.org/10.1016/j.zool.2018.06.005 
Barassa B., Arana S. \& Cordeiro N.C. 2003. A new species of Henneguya, a gill parasite of Astyanax altiparanae (Pisces: Characidae) from Brazil, with comments on histopathology and seasonality. Memórias do Instituto Oswaldo Cruz 98: 761-765. https://doi.org/10.1590/S0074-02762003000600009

Camus A.C. \& Griffin M.J. 2010. Molecular characterization and histopathology of Myxobolus koi infecting the gills of a koi, Cyprinus carpio, with an amended morphological description of the agent. Journal of Parasitology 96: 116-124. https://doi.org/10.1645/GE-2113.1

Camus A.C., Dill J.A., Rosser T.G., Pote L.M. \& Griffin M.J. 2017. Myxobolus axelrodi n. sp. (Myxosporea: Myxobolidae) a parasite infecting the brain and retinas of the cardinal tetra Paracheirodon axelrodi (Teleostei: Characidae). Parasitology Research 116: 387-397.

https://doi.org/10.1007/s00436-016-5301-1

Capodifoglio K.R.H., Adriano E.A., Silva M.R.M. \& Maia A.A.M. 2019. The resolution of the taxonomic dilemma of Myxobolus colossomatis and description of two novel myxosporeans species of Colossoma macropomum from Amazon basin. Acta Tropica 191: 17-23.

https://doi.org/10.1016/j.actatropica.2018.12.026

Crawshaw M.T. \& Sweeting R.A. 1986. Myxobolus koi Kudo, 1919: a new record for Britain. Journal of Fish Diseases 9 (5): 465-467. https://doi.org/10.1111/j.1365-2761.1986.tb01041.x

Eiras J.C., Zhang J.Y. \& Molnár K. 2014. Synopsis of the species of Myxobolus Butschli, 1882 (Myxozoa: Myxosporea, Myxobolidae) described between 2005 and 2013. Systematic Parasitology 88: 11-36. https://doi.org/10.1007/s11230-014-9484-5

Froese R. \& Pauly D. 2011. Corydoras schwartzi. FishBase: World Wide Web electronic publication. Available from www.fishbase.org [accessed 10 Jan. 2019].

Hallett S.L., Hartigan A. \& Atkinson S.D. 2015. Myxozoans on the move: dispersal modes, exotic species and emerging diseases. In: Okamura B., Gruhl A. \& Bartholomew J.L. (eds) Myxozoan Evolution, Ecology and Development: 343-362. Springer, Cham, Switzerland.

Junk W.J., Soares M.G.M. \& Bayley P.B. 2007. Freshwater fishes of the Amazon River basin: their biodiversity, fisheries, and habitats. Aquatic Ecosystem Health \& Management 10: 153-173.

https://doi.org/10.1080/14634980701351023

Lom J. \& Arthur J.R. 1989. A guideline for the preparation of species descriptions in Myxosporea. Journal of Fish Diseases 12 (2): 151-156. https://doi.org/10.1111/j.1365-2761.1989.tb00287.x

Mathews P.D., Silva M.R.M, Maia A.A.M. \& Adriano E.A. 2015. Ultrastructure and ssrRNA sequencing of Myxidium amazonense n. sp. a myxosporean parasite of Corydoras melini from the Rio Negro River, Amazonas state, Brazil. Parasitology Research 114: 4675-4683.

https://doi.org/10.1007/s00436-015-4715-5

Mathews P.D., Maia A.A.M. \& Adriano E.A. 2016. Morphological and ultrastructural aspects of Myxobolus niger n. sp. (Myxozoa) gill parasite of Corydoras melini (Siluriformes: Callichthyidae) from Brazilian Amazon. Acta Tropica 158: 214-219. https://doi.org/10.1016/j.actatropica.2016.03.016

Mathews P.D., Naldoni J. \& Adriano E.A. 2017. Morphology and small subunit rDNA-based phylogeny of a new Henneguya species, infecting the ornamental fish Corydoras leucomelas from the Peruvian Amazon. Acta Tropica 176: 51-57. https://doi.org/10.1016/j.actatropica.2017.07.017

Mathews P.D., Mertins O., Pereira J.O.L., Maia A.A.M. \& Adriano E.A. 2018. Morphology and 18S rDNA sequencing of Henneguya peruviensis n. sp. (Cnidaria: Myxosporea), a parasite of the Amazonian ornamental fish Hyphessobrycon loretoensis from Peru: A myxosporean dispersal approach. Acta Tropica 187: 207-213. https://doi.org/10.1016/j.actatropica.2018.08.012 
Matos E., Videira M., Velasco M., Sanches O., Carmona C.S. \& Matos P. 2014. Infection of the heart of Pimelodus ornatus (Teleostei, Pimelodidae), by Myxobolus sp. (Myxozoa, Myxobolidae). Revista Brasileira de Parasitologia Veterinária 23 (4): 543-546. https://doi.org/10.1590/s1984-29612014083

Molnár K. 2002. Site preference of fish myxosporeans in the gill. Diseases of Aquatic Organisms 48: 197-207. https://doi.org/10.3354/dao048197

Molnár K. \& Békési L. 1993. Description of a new Myxobolus species: M. colossomatis n. sp. from the teleost Colossoma macropomum of the Amazon River basin. Journal of Applied Ichthyology 9: 57-63. https://doi.org/10.1111/j.1439-0426.1993.tb00388.x

Molnár K. \& Eszterbauer E. 2015. Specificity of infection sites in vertebrate hosts. In: Okamura B., Gruhl A. \& Bartholomew J.L. (eds) Myxozoan Evolution, Ecology and Development: 295-313. Springer, Cham, Switzerland.

Molnár K. \& Székely C. 2014. Tissue preference of some myxobolids (Myxozoa: Myxosporea) from the musculature of European freshwater fishes. Diseases of Aquatic Organisms 107: 191-198.

https://doi.org/10.3354/dao02688

Morand S. \& Guégan J.F. 2000. Patterns of endemism in host-parasite associations: lessons from epidemiological models and comparative tests. Belgian Journal of Entomology 2: 135-147.

Moreau M.A. \& Coomes O.T. 2007. Aquarium fish exploitation in western Amazonia: conservation issues in Peru. Environmental Conservation 34: 12-22. https://doi.org/10.1017/S0376892907003566

Naldoni J., Arana S., Maia A.A.M., Ceccarelli P.S., Tavares L.E.R., Borges F.A., Pozo C.F. \& Adriano E.A. 2009. Henneguya pseudoplatystoma $\mathrm{n}$. sp. causing reduction in epithelial area of gills in the farmed pintado, a South American catfish: histopathology and ultrastructure. Veterinary Parasitology 166: 5259. https://doi.org/10.1016/j.vetpar.2009.07.034

Naldoni J., Maia A.A.M., Correa L.L., Da Silva M.R.M. \& Adriano E.A. 2018. New myxosporeans parasitizing Phractocephalus hemioliopterus from Brazil: morphology, ultrastructure and SSU-rDNA sequencing. Diseases of Aquatic Organisms 128: 37-49. https://doi.org/10.3354/dao03210

Okamura B., Gruhl A. \& Bartholomew J.L. 2015. An introduction to Myxozoan evolution, ecology and development. In: Okamura B., Gruhl A. \& Bartholomew J.L. (eds) Myxozoan Evolution, Ecology and Development:1-20. Springer, Cham, Switzerland.

Padrós F., Palenzuela O., Hispano C., Tosas O., Zarza C., Crespo S. \& Alvarez-Pellitero P. 2001. Myxidium leei (Myxozoa) infections in aquarium-reared Mediterranean fish species. Diseases of Aquatic Organisms 47: 57-62. https://doi.org/10.3354/dao047057

Penido J.C.N. 1927. Quelques nouvelles myxosporidies parasites des poissons d'eau douce du Brésil. Comptes Rendus de la Société brésilienne de Sciences naturelles 97: 850-852.

Prang G. 2007. An industry analysis of the freshwater ornamental fishery with particular reference to the supply of Brazilian freshwater ornamentals to the UK market. Uakari 3: 7-51.

https://doi.org/10.31420/uakari.v3i1.18

Reis R.E. 1998. Systematics, biogeography, and the fossil record of the Callichthyidae: a review of the available data. In: Malabarba L.R., Reis R.E., Vari R.P., Lucena Z.M.S. \& Lucena C.A.S. (eds) Phylogeny and Classification of Neotropical Fishes: 351-362. Edipucrs, Porto Alegre, Brazil.

Saha M. \& Bandyopadhyay P.K. 2017. Studies on histopathological alteration of three major organs of the goldfish, Carassius auratus L., of India due to myxozoan infection with special reference to scanning electron microscopic observation. Parasitology Research 116: 511-520.

https://doi.org/10.1007/s00436-016-5314-9 
Sindeaux-Neto J.L., Velasco M., Da Silva J.M.V, Dos Santos P.F.S., Sanches O., Matos P. \& Matos E. 2016. Lymphocytic meningoencephalomyelitis associated with Myxobolus sp. (Bivalvulidae: Myxozoa) infection in the Amazonian fish Eigenmannia sp. (Sternopygidae: Gymnotiformes). Revista Brasileira de Parasitologia Veteterinária 25: 158-162. https://doi.org/10.1590/S1984-29612016023

Velasco M., Videira M., Nascimento L.C., Matos P., Gonçalves E.C. \& Matos E. 2016. Henneguya paraensis n. sp. (Myxozoa; Myxosporea), a new gill parasite of the Amazonian fish Cichla temensis (Teleostei: Cichlidae): morphological and molecular aspects. Parasitology Research 115: 1779-1787. https://doi.org/10.1007/s00436-016-4916-6

Vidal L.P., Iannacone J., Whipps C.M. \& Luque J.L. 2017. Synopsis of the species of Myxozoa Grassé, 1970 (Cnidaria: Myxosporea) in the Americas. Neotropical Helminthology 11: 413-511.

Wang M., Zhao Y. \& Yang C. 2019. The impacts of geographic and host species isolation on population divergence of Myxobolus lentisuturalis. Parasitology Research 118: 1061-1066.

https://doi.org/10.1007/s00436-019-06234-9

Whipps C.M. \& Kent M.L. 2006. Phylogeography of the cosmopolitan marine parasite Kudoa thyrsites (Myxozoa: Myxosporea). Journal of Eukaryotic Microbiology 53: 364-373.

https://doi.org/10.1111/j.1550-7408.2006.00114.x

Zatti S.A., Atkinson S.D., Maia A.A.M., Bartholomew J.L. \& Adriano E.A. 2018a. Novel Henneguya spp. (Cnidaria: Myxozoa) from cichlid fish in the Amazon basin cluster by geographic origin. Parasitology Research 117: 849-859. https://doi.org/10.1007/s00436-018-5762-5

Zatti S.A., Atkinson S.D., Maia A.A.M., Bartholomew J.L. \& Adriano E.A. 2018b. Ceratomyxa gracillima n. sp. (Cnidaria: Myxosporea) provides evidence of panmixia and ceratomyxid radiation in the Amazon basin. Parasitology 145: 1137-1146. https://doi.org/10.1017/S0031182017002323

Zhang Z.Q. 2013. Animal biodiversity: an update of classification and diversity in 2013. Zootaxa 3703: 5-11. https://doi.org/10.11646/zootaxa.3703.1.3

Manuscript received: 31 August 2019

Manuscript accepted: 13 December 2019

Published on: 30 March 2020

Topic editor: Rudy Jocqué

Desk editor: Danny Eibye-Jacobsen

Printed versions of all papers are also deposited in the libraries of the institutes that are members of the EJT consortium: Muséum national d'histoire naturelle, Paris, France; Meise Botanic Garden, Belgium; Royal Museum for Central Africa, Tervuren, Belgium; Royal Belgian Institute of Natural Sciences, Brussels, Belgium; Natural History Museum of Denmark, Copenhagen, Denmark; Naturalis Biodiversity Center, Leiden, the Netherlands; Museo Nacional de Ciencias Naturales-CSIC, Madrid, Spain; Real Jardín Botánico de Madrid CSIC, Spain; Zoological Research Museum Alexander Koenig, Bonn, Germany; National Museum, Prague, Czech Republic. 